\author{
Marcin ŁuKasz MajewsKi \\ Katolicki Uniwersytet LUbelski, Lublin
}

\title{
UDZIAŁ KUPCÓW ORMIAŃSKICH \\ W HANDLU WINEM W PIOTRKOWIE W XVII I XVIII WIEKU
}

W 1850 roku wybitny krajoznawca i wychowanek piotrkowskiego Gimnazjum Rządowego, Oskar Flatt, opisując atrakcje turystyczne Piotrkowa, stwierdził, że „najgłośniejsze [...], najzasłużeńszą cieszące się sławą, są piwnice Piotrkowskie”. Swą opinię uzasadniał tym, że „w niektórych znajdują się wina, które by jeszcze coś o zeszłym wieku i o Palestrze przypomnieć umiały"1. W innym szkicu o mieście wspominał o „królowej” owych słynnych piwnic należącej do niejakiego Mikułowskiego, wyrażając żal, że po śmierci sędziwego mieszczanina jego spadkobiercy wyprzedali wartą fortunę kolekcję win ,pamiętających” dobrze czasy obrad trybunalskiej palestry². Nic więc dziwnego, że Aleksander Weryha-Darowski właśnie Flattowi przypisał autorstwo przysłowia: „Piotrków słynie winem i pannami"’.

W słowach Flatta trudno dopatrywać się przesady, ponieważ istotnie wino było głównym produktem, na którego sprzedaży w XVII i XVIII wieku piotrkowski patrycjat dorobił się ogromnych majątków. Handel tym dobrem był jednym z głównych dochodów także dla osiedlających się w mieście kupców ormiańskich ${ }^{4}$. Zachowane źródła, pomimo szczątkowego charakteru, dają moż-

\footnotetext{
${ }^{1}$ O. Flatt, Opis Piotrkowa Trybunalskiego pod względem historycznym i statystycznym, Warszawa 1850, s. 26.

${ }^{2}$ Idem, Piotrków dziś i przed dwudziestu laty, w: J. Jaw orski, Kalendarz astronomiczno-gospodarski na rok zwyczajny 1854. Opisów roślin rok siedemnasty, Warszawa 1854, s. 121.

3 A. Weryha-Darowski, Przysłowia polskie odnoszace się do nazwisk szlacheckich i miejscowości, Poznań 1874, s. 173.

${ }^{4}$ M. Ł. Majewski, Wegrzy, Szkoci i Ormianie. Studia nad składem etnicznym mieszkańców Piotrkowa przyjętych do prawa miejskiego w okresie staropolskim, Warszawa 2017, s. 85.
} 
liwość prześledzenia aktywności handlowej Ormian i określenia ich miejsca na piotrkowskim rynku handlu tym szlachetnym trunkiem.

Początkowo Ormianie nie odgrywali większej roli w imporcie wina. Handel najbardziej popularnymi w XVI wieku małmazją i muszkatelą, sprowadzanymi z Peloponezu i Krety, był zdominowany przez kupców nacji śródziemnomorskich - Greków i Włochów ${ }^{5}$. Zachowane źródła potwierdzają, że tak było również w Piotrkowie. Jedna z pierwszych wzmianek o handlu winem w tym mieście wspomina o greckim kupcu z Kandii, który w czasie obrad sejmowych przebywał w Piotrkowie, handlując małmazją i muszkatelą ${ }^{6}$. Natomiast zachowany XVI-wieczny rejestr czopowego wymienia nieznanego z imienia Włocha, który w handlu winem i małmazją znacząco dystansował innych kupców?

Pomimo tego, że wraz z upływem czasu Ormianie włączyli się w import do Rzeczypospolitej zarówno win greckich, jak i wołoskich oraz węgierskich ${ }^{8}$, towaru tego nie dostarczali do Piotrkowa aż do przedostatniej dekady XVII wieku. Pierwsi notowani w piotrkowskich źródłach Ormianie handlowali głównie safianami oraz różnego rodzaju tkaninami. Byli także dostawcami świec i perfum, a z produktów spożywczych - ryb, pierników, kawy i przypraw ${ }^{9}$. Brak zainteresowania importem i dystrybucją win wynikał najprawdopodobniej z dość silnej konkurencji, z którą musieliby się spotkać na rynku piotrkowskim. W dostarczaniu skór i tkanin kupcy ormiańscy byli monopolistami, podczas gdy rynek winiarski był zdominowany przez handlarzy z Węgier. Wystarczy wspomnieć, że w poszczególnych latach między rokiem 1670 a 1680 pochodzący z Węgier kupcy zaopatrywali w wino od $40 \%$ do $80 \%$ piotrkowskich winiarni, a w latach 1674-1675 byli nawet wyłącznymi dostawcami tego trunku ${ }^{10}$. Możliwości wejścia na lokalny rynek handlu winem były więc mocno ograniczone. Nie inaczej było w przypadku kupców, którzy przyjęli piotrkowskie prawo miejskie i osiedli w mieście na stałe. Środowisko handlarzy winem składało się z najbogatszych przedstawicieli kupieckiej profesji. W latach 80 . XVII wieku, kiedy w handel szlachetnym trunkiem zaczęli się angażować pierwsi Ormianie, liczyło ono mniej niż 10 osób ${ }^{11}$.

${ }^{5}$ A. Dziubiński, Na szlakach Orientu. Handel między Polska a Imperium Osmańskim w XVI-XVIII wieku, Wrocław 1998, s. 189.

${ }^{6}$ M. Rawita-Witanow ski, Monografia Piotrkowa Trybunalskiego, Piotrków Trybunalski 2017 , s. 575.

7 Archiwum Główne Akt Dawnych (dalej: AGAD): Archiwum Skarbu Koronnego, dział I (dalej: ASK I), sygn. 25, mkf. 4150, k. 781v.

${ }^{8}$ G. Pełczyński, Polska - Ormianie - Wschód, w: Ormianie, red. B. Machul-Telus, Warszawa 2014, s. 68.

${ }_{9}$ M. Ł. Majewski, Kupcy ormiańscy w mieście staropolskim na przyktadzie Piotrkowa Trybunalskiego, w: Ormianie - historia i kultura. Sesja naukowa Szreniawa, 24-25 czerwca 2017, red. A. A. Zięba, Szreniawa 2017, s. 43 i n.

${ }_{10}$ M. Ł. Majewski, Wegrzy, Szkoci i Ormianie, s. 32.

${ }_{11}$ Archiwum Państwowe w Piotrkowie Trybunalskim (dalej: APPT): Cech Kupców w Piotrkowie (dalej: CKP), sygn. 32, Rejestr Bractwa Kupieckiego. Kwartalne wptywy $i$ wydatki 1670-1731, s. 139 i n., 147, 153. 
Pierwszym Ormianinem, który podjął próbę wejścia na piotrkowski rynek handlu alkoholem, był Krzysztof Derjakubowicz. Przebywał w Piotrkowie co najmniej od drugiej połowy lat 50. XVII stulecia i handlował różnymi tkaninami. Choć w tym czasie Derjakubowicz nie należał jeszcze do miejskiej elity, wydarzenia związane z potopem szwedzkim i bankructwem wielu spółek kupieckich umożliwiły przedsiębiorczemu Ormianinowi wejście w kręgi piotrkowskiego patrycjatu. Z możliwości tej skorzystał również szmuklerz Stefan Wierzbicz, z którym Derjakubowicz prowadził interesy handlowe ${ }^{12}$. Obaj kupcy świetnie wykorzystując spowodowaną wojną dekoniunkturę, w znaczący sposób podnieśli swe stany majątkowe i pozycję społeczną. W przeciwieństwie do Wierzbicza Derjakubowicz nie zdecydował się na przebranżowienie swojej działalności. Widocznie ormiański kupiec nie widział w tym czasie takiej potrzeby, zwłaszcza że zmiana pola działania wiązała się z posiadaniem dużego kapitału oraz znacznym ryzykiem. W ciągu lat 60 . XVII wieku Derjakubowiczowi udało się jednak zbić pokaźny majątek. Przez trzy następne dekady był on najbogatszym kupcem w Piotrkowie, z którym pod względem zamożności mógł się równać tylko Szkot, Jerzy Burnet. Uzyskiwane z działalności handlowej nadwyżki mogły być lokowane $\mathrm{w}$ gruntach i nieruchomościach oraz inwestowane $\mathrm{w}$ handel innym towarem. Inwestycja taka była korzystna z dwóch względów. Po pierwsze, pozwalała kupcowi specjalizującemu się w handlu wyłącznie jednym towarem na uniezależnienie się od ewentualnej dekoniunktury. Perspektywa posiadania alternatywnego źródła dochodów mogła uchronić przed bankructwem. Po drugie, lokata kapitału w rozszerzenie działalności handlowej mogła, pod warunkiem rozsądnego wchodzenia na nowy rynek, dawał zwiększenie zysków. W Piotrkowie zaś największe zyski dawał handel winem, na które w czasie zjazdów trybunalskich był znaczny popyt.

W handel tym trunkiem Derjakubowicz włączył się w 1684 roku. Na podstawie zapisków z akt Konfraterni Kupieckiej można wywnioskować, że pierwsze inwestycje były bardzo ostrożne. W 1684 roku sprowadził jedynie dwie beczki wina, co stanowiło zaledwie 3\% przywiezionego do Piotrkowa trunku ${ }^{13}$. Udział Ormianina w lokalnym rynku winiarskim był więc niewielki. Podobnie było w następnych latach. W 1686 roku, kiedy do Piotrkowa przywieziono ogółem 77 beczek, do piwnic Derjakubowicza trafiło sześć, co stanowiło 7,7\%. Ormianin zakupił najmniejszą poza Łukaszem Ledzim ilość towaru. Dla porównania w składzie Alberta Brydaka znalazło się aż 59,7\% beczek wina dostarczonych w tym roku do Piotrkowa ${ }^{14}$.

\footnotetext{
${ }_{12}$ M. Ł. Majewski, Wegrzy, Szkoci i Ormianie, s. 149.

13 APPT: CKP, sygn. 32, s. 139.

14 Ibidem, s. 158.
} 
Niestety nie wiadomo, gdzie Derjakubowicz zaopatrywał się w wino oraz jaki gatunek sprowadzał do swoich piwnic. Zdaniem Michała Rawity-Witanowskiego - badacza, który jako ostatni widział zniszczone w latach II wojny światowej akta miejskie - Ormianie specjalizowali się w handlu winami świętojurskimi, sprowadzanymi ze Lwowa ${ }^{15}$. Biorąc pod uwagę, że Lwów zamieszkały był przez liczną kolonię ormiańską, a Ormianie piotrkowscy prowadzili interesy handlowe, utrzymując kontakty ze swoimi ziomkami, stwierdzenie to wydaje się bardzo prawdopodobne. Możliwy jednak jest i inny kierunek importu. Wino świętojurskie sprowadzali bowiem kupcy krakowscy. Notabene to właśnie z Krakowa - największego ośrodka handlu winem w dobie staropolskiej, sprowadzali je kupcy lwowscy ${ }^{16}$. Pamiętać przy tym należy, że Piotrków posiadał o wiele lepsze połączenie handlowe z Krakowem niż ze Lwowem. Podczas gdy kupiec udający się do Lwowa kierował się długą drogą na południowy wschód przez Sulejów, Opoczno i Wąchock, następnie w Kopkach wybierał trakt przez Krzeszów i Lubaczów lub Jarosław i Przemyśl, szlak do dawnej stolicy królestwa wiódł go prosto na południe przez Sulejów, Przedbórz, Radoszyce, Kurzelów i Miechów ${ }^{17}$. Na zaopatrywanie się Derjakubowicza właśnie w Krakowie może wskazywać wzmianka z 4 stycznia 1693 roku. Tego dnia niejaki Kutowski dostarczył sześć beczek wina zamówionych wspólnie przez Wojciecha Wierzbicza i Krzysztofa Derjakubowicza $^{18}$. Obaj kupcy prowadzili ze sobą interesy jeszcze w czasie, kiedy Wierzbiczowie trudnili się szmuklerstwem. Co istotne, już wtedy Kraków był dla nich najważniejszym rynkiem zaopatrzenia w towar ${ }^{19}$.

Bez względu na to, skąd Derjakubowicz sprowadzał wino, w dalszym ciągu nie były to duże ilości. W 1694 roku w jego piwnicach znalazło się 5 beczek, podczas gdy u Alberta Brydaka - 28, Jerzego Parkasza - 10, a Wierzbicza - 8. Poza nimi opłatę od wina uiścili jeszcze Kacper Pejczer (5 beczek) i bliżej nieznany Zygmunt (14 beczek) ${ }^{20}$. Wraz z Kacprem Pejczerem Derjakubowicz miał więc najmniejszy udział na piotrkowskim rynku winiarskim. Pomimo że w następnym roku ilość zamówionego przez Ormianina trunku zwiększyła się do 10 beczek, w dalszym ciągu stanowiło to nieco powyżej $7 \%{ }^{21}$. Należy jednak mieć na uwadze, że sporządzane przez Konfraternię Kupiecką rejestry wymieniają nazwiska kupców piotrkowskich tylko wtedy, gdy to oni uiszczali u poborców opłatę za

${ }^{15}$ M. Rawita-Witanowski, Monografia, s. 715.

${ }^{16}$ R. Marcinek, Rex vinorum. Z dziejów węgrzyna w dawnej Polsce, Warszawa 2015, s. 203.

17 S. Lewicki, Drogi handlowe $w$ Polsce $w$ wiekach średnich $i$ wieku XVI, Warszawa 1926.

18 APPT: CKP, sygn. 32, s. 177.

19 Archiwum Narodowe w Krakowie (dalej: ANK): Akta Miasta Krakowa (dalej: AMK), Regestra thelonei civitatis Cracoviensis, sygn. 2145-2165.

20 APPT: CKP, sygn. 32, s. 177.

${ }^{21}$ Ibidem, s. 209-210. 
przywieziony przez swoich dostawców towar. Do rzadkości jednak nie należały sytuacje, kiedy bezpośrednim płatnikiem był dostawca. W 1695 roku opłaty od łącznie 60 beczek szlachetnego trunku uiściło 4 dostawców. Ponieważ rejestr nie notuje nawet ich imion, nie wiadomo komu dostarczali swój towar. $Z$ tego też powodu nie jest znana ilość wina sprowadzanego przez Derjakubowicza w następnych latach. Z dużą dozą prawdopodobieństwa można jedynie stwierdzić, że w 1697 roku sprowadził do swoich piwnic co najmniej pięć beczek wina śląskiego $^{22}$. Nie jest wymieniony jako płatnik podatku, ale z późniejszych zapisków wynika, że Derjakubowiczowie byli jedyną rodziną kupiecką w Piotrkowie, która importowała wino śląskie ${ }^{23}$. Nawiązane przez Derjakubowicza pod koniec jego życia kontakty handlowe ze Śląskiem miały ogromne znaczenie, ponieważ w czasie wielkiej wojny północnej uratowały jego spadkobierców przed bankructwem.

Przedstawiona powyżej działalność Derjakubowicza na piotrkowskim rynku winiarskim pozwala stwierdzić, że początkowo wino nie było głównym towarem, którym handlował. Sprzedaż tego trunku traktował wyłącznie jako zajęcie dodatkowe. W latach aktywności ormiańskiego kupca rynek alkoholowy w Piotrkowie był zdominowany przez innych, zwłaszcza Alberta Brydaka. Kwestia ta jest warta odnotowania, ponieważ Rawita-Witanowski zaliczył Derjakubowicza do grupy kupców, którzy w latach 1671-1697 dominowali w handlu winem ${ }^{24}$. Na uwagę jednak zasługuje fakt, że wraz z upływem czasu zaangażowanie Derjakubowicza w handel szlachetnym trunkiem rosło, gdyż on sam, dostrzegając monopolizację rynku przez kilku kupców, szukał nowych kierunków importu. Stąd nastąpiło zwrócenie uwagi na Śląsk. Analizując działalność Derjakubowicza oraz zważając, że dla jego następców handel winem był już wyłącznym źródłem dochodów, można stwierdzić, że w latach 80. i 90. XVII wieku dokonywał stopniowego przebranżowienia swojego przedsiębiorstwa handlowego.

Wzmianki z przełomu XVII i XVIII wieku są zbyt lakoniczne, by odpowiedzieć na pytanie, jak interes handlowy Derjakubowicza rozwijał się pod zarządem jego następców. Informacje o ilości sprowadzonego przez Derjakubowiczów wina zachowały się jedynie z lat 1702 i 1704. W 1702 roku importowali 9 beczek trunku, plasując się daleko w tyle za Marcinem Sonabendem (34 beczki), Grudelą (26 beczek), Albertem Brydakiem (19 beczek) i Wierzbiczem (13 beczek $)^{25}$. Dla wspomnianych kupców był to jednak ostatni rok względnej prosperity. Zajęcie Krakowa przez armię szwedzką w sierpniu 1703 roku i działania zbrojne toczone na południu Polski skutecznie zdezorganizowały handel szlachetnym trunkiem. Również zajęcie Piotrkowa, poczynione przez okupacyjne wojska zniszczenia i nałożona na miasto kontrybucja mocno odbiły się na majątku kupców, a co

${ }^{22}$ Ibidem, s. 221

${ }^{23}$ M. Ł. Majewski, Wegrzy, Szkoci i Ormianie, s. 90.

${ }^{24}$ M. Rawita-Witanowski, Monografia, s. 714.

25 APPT: CKP, sygn. 32, s. 257 i n. 
za tym idzie - skali prowadzonych przez nich interesów. W przypadku handlu winem zjawisko to najlepiej obrazuje ilość trunku sprowadzanego do Piotrkowa. Podczas gdy w 1702 roku były to aż 134 beczki, a rok później 104, to w roku 1704 tylko $29^{26}$. W tym czasie wino udało się sprowadzić jedynie czterem piotrkowskim kupcom: Sonabendowi, Brydakowi, Wierzbiczowi i Katarzynie Derjakubowiczowej. Wszyscy, poza pierwszym, który zdołał przetransportować 11 beczek, sprowadzili po 6 beczek $^{27}$. Okoliczności wojenne sprawiły więc, że udział Derjakubowiczów w miejscowym rynku wzrósł do ponad 20\%. Nie wiadomo, czy tendencja ta utrzymała się w kolejnych latach ze względu na brak wzmianek w zachowanych źródłach. W tym czasie Michał Derjakubowicz awansował zarówno w hierarchii cechu kupieckiego, jak i w lokalnym samorządzie, więc prowadzone przez niego i jego matkę interesy handlowe musiały mieć się dobrze. Spowodowany wielką wojną północną kryzys i wywołane nim bankructwa wielu spółek kupieckich w poważny sposób zmieniły piotrkowski rynek winiarski.

Istniejący w dwóch ostatnich dekadach XVII wieku monopol kilku kupców, w dużej mierze kontrolujących handel winem, został przerwany. Otwierało to szerokie perspektywy przed kupcami przybyłymi z zewnątrz lub tymi, których dekoniunktura dotknęła w znacznie mniejszym stopniu. Powstałą niszę skutecznie zagospodarowali osiadli w Piotrkowie kupcy ormiańscy.

W 1709 roku, kiedy w piotrkowskim handlu winem regres był nadal odczuwalny, sprowadzono zaledwie 17 beczek szlachetnego trunku. Warto jednak zwrócić uwagę, że aż osiem, czyli niemal połowa, zostało przywiezionych do piwnic należących do Nazara Antoniewicza ${ }^{28}$. Udział Ormianina w handlu alkoholem zwiększał się w kolejnych latach. W 1714 roku sprowadził 36 beczek trunku, co oznaczało, że w jego dyspozycji znajdowało się aż 83,7\% wina przywiezionego w tym roku do Piotrkowa ${ }^{29}$. Rok ten był ostatnim rokiem kryzysu dla piotrkowskiego rynku winiarskiego. W 1715 roku do miasta dostarczono 140 beczek, ale zostały one sprowadzone wyłącznie przez dwie rodziny kupieckie: Wierzbiczów i Antoniewiczów. Nazar w dalszym ciągu zachował status monopolisty. Podczas gdy do Wierzbiczów trafiło 60 beczek wina, do Antoniewicza aż 80, czyli ponad $57 \%{ }^{30}$. Podobnie jak w przypadku Derjakubowiczów, nie wiadomo, skąd Nazar sprowadzał towar. Zachowane źródła wskazują natomiast, że korzystał on z usług dostawców ormiańskich. W 1709 roku zamówione przez Antoniewicza wino zostało przywiezione przez bliżej nieznanego Ohana, zaś w roku 1715 dostawcą był niejaki Garabed (Garabit/Garabiet) ${ }^{31}$.

26 Ibidem, s. 263 i n., 270.

27 Ibidem, s. 270.

28 Ibidem, s. 298.

29 Ibidem, s. 304.

30 Ibidem, s. 315.

31 Ibidem, s. 298, 315. 
Po 1715 roku zapiski sporządzane przez władze Konfraterni Kupieckiej cechuje coraz większa lakoniczność, w związku z czym o aktywności Ormian w handlu winem w latach 1715-1731 niewiele można powiedzieć. Szczątkowe informacje wskazują jednak, że na rynku winiarskim odgrywali oni w tym czasie rolę dominującą. W 1723 roku Nazar Antoniewicz sprowadził 10 beczek wina, zaś prowadzący już od kilku lat interesy w Piotrkowie Stefan Augustynowicz aż 72 beczki ${ }^{32}$. Niestety nie wiadomo, ile wina w owym roku przywieziono ogółem do Piotrkowa. Z pewnością Antoniewicz i Augustynowicz nie byli jedynymi kupcami ormiańskimi handlującymi tym trunkiem. W latach 1715-1731 handlem winem zajmował się również Gabriel Balsamowicz ze Lwowa, nie zachowała się jednak informacja, w jakiej ilości je sprowadzał.

O imporcie przez kupców ormiańskich dużej ilości wina w tym czasie świadczy wysokość czopowego uiszczonego za lata 1730-1731 przez Nazara Antoniewicza. Według zachowanych akt skarbowych zapłacił on 121 zł podatku ${ }^{33}$. $\mathrm{Na}$ tej podstawie nie można stwierdzić, jaką ilość trunku sprowadził do swoich piwnic, ponieważ poza handlem szlachetnym trunkiem Antoniewicz był również zaangażowany $\mathrm{w}$ produkcję i sprzedaż piwa ${ }^{34}$. Z pewnością jednak większość opłaty dotyczyła wina, a jego ilość można szacować na co najmniej kilkadziesiąt beczek. W latach 30. i 40. XVIII wieku Antoniewiczowie w dalszym ciągu byli w Piotrkowie jednymi z najważniejszych importerów wina. W 1735 roku dostawcy Nazara przywieźli do jego piwnic 12,5 beczki trunku, podczas gdy inni kupcy sprowadzili od 6 do 8 beczek $^{35}$.

Była to ostatnia transakcja handlowa przeprowadzona przez Nazara, gdyż w tym samym roku zmarł. Jego interesy odziedziczyła żona Anna, która przez następne lata aktywnie działała na miejscowym rynku winiarskim. Co prawda w 1736 roku sprowadziła jedynie 6 beczek, ale już w następnym roku do przyrynkowej kamienicy, której była właścicielką, spuszczono aż 62 beczki ${ }^{36}$. Stanowiło to $40 \%$ wina przywiezionego w tym roku do miasta. Najmniejszy udział w rynku miała Antoniewiczowa w latach 1738 i 1740. Wynosił on odpowiednio 19,5\% i 9,6\% ${ }^{37}$. W latach 1741 i 1743-1744 w posiadaniu Antoniewiczowej znajdowało

${ }^{32}$ Ibidem, s. 335, 338.

33 AGAD: Sumariusze i księgi pomocnicze urzędu grodzkiego sieradzkiego oraz varia z akt ziemskich i grodzkich wielkopolskich (dalej: Sumariusz Sieradz.), sygn. 38, Wypisy dekretów odnośnie czopowego z miast województwa sieradzkiego, k. 12.

${ }^{34}$ M. Ł. Majewski, Piwowarstwo miejskie w Piotrkowie w XVI-XVIII wieku (niepublikowane opracowanie).

35 APPT: CKP, sygn. 7, Akta Bractwa Kupieckiego Piotrkowskiego 1722-1759. Protokoty sesji, s. 205. W 1735 roku 14 beczek wina zostało dostarczonych do Piotrkowa przez nieznanego Garbulego (Garbulewicza). Najpewniej przywiezione przez niego wino trafiło do co najmniej dwóch kupców.

36 Ibidem, s. 210, 215.

37 Ibidem, s. 212, 221. 
się od ponad $25 \%$ do prawie $43 \%$ przywożonego do Piotrkowa trunku. W 1741 roku dostarczono jej 16 beczek, zaś w latach 1743-1744 po $6^{38}$. Jedne z ostatnich wzmianek o działalności handlowej Antoniewiczowej pochodzą z lat 1749-1750. W jej piwnicach znalazło się w tych latach ogółem 16,5 beczki, czyli 13,6\% wina przywiezionego w tym okresie do Piotrkowa ${ }^{39}$. Po raz ostatni aktywność Anny Antoniewiczowej została odnotowana w źródłach w 1753 roku, kiedy uiściła ona opłatę za transport ${ }^{40}$. Nie wiadomo, jaki towar został dostarczony do jej kamienicy. Mogło być to wino, ale równie dobrze produkty potrzebne do produkcji piwowarskiej - zboże, chmiel lub ześrutowany w młynie słód ${ }^{41}$.

Analiza ilości wina sprowadzanego w poszczególnych latach przez ormiańskich kupców pozwala na wyróżnienie dwóch sposobów importowania szlachetnego trunku. Pierwszy polegał na zakupie, co jakiś czas, dużej ilości wina uzupełnianej w międzyczasie mniejszymi dostawami. W taki sposób wino importowali Antoniewiczowie. Innym sposobem był zakup co kilka lat bardzo dużej ilości trunku. W ten sposób interes prowadził Stefan Augustynowicz, który raz na kilka lat sprowadzał jednorazowo do swych piwnic po 72 beczki wina ${ }^{42}$.

$\mathrm{Z}$ całą pewnością taki sposób importu szlachetnego trunku obarczony był dużo większym ryzykiem niż regularne zakupy, których ilość zależała od aktualnego zapotrzebowania. Przede wszystkim, choć handel winem był intratnym interesem, wymagał bardzo dużych nakładów finansowych. Poza tym, że kupiec płacił za towar, pokrywał też koszty transportu, podatku na rzecz państwa, a także Konfraterni Kupieckiej, która pobierała opłatę od każdej sprowadzonej beczki. W tej sytuacji niewielu spośród kupców mogło sobie pozwolić na prowadzenie rozległych interesów bez konieczności zaciągania pożyczek. Nic więc dziwnego, że długi Augustynowicza z tytułu pożyczek zaciąganych na prowadzenie kosztownego interesu rosły w zastraszającym tempie. O ile Antoniewiczowie, opusz-

38 Ibidem, s. 223, 232, 234.

39 Ibidem, s. 241, 243.

40 Ibidem, s. 247.

${ }^{41}$ Nie wiadomo, jak w średniowiecznym i staropolskim Piotrkowie zorganizowany był transport słodu. Przewóz tego surowca należał najprawdopodobniej do prerogatyw miasta lub, co równie prawdopodobne, do miejscowych młynarzy. Wiadomo, że młyn królewski, w którym mieszczanie mielili słód, posiadał woły, najpewniej wykorzystywane do transportu, zob.: M. Ł. Majewski, Piwowarstwo. Antoniewiczowa mogła transportować słód sama, zwłaszcza że była właścicielką folwarku przy Rokszyckim Przedmieściu. Majątek ten położony był przy ówczesnej ul. Toruńskiej między placem zwanym Rodawszczyzną a klasztorem bernardynów i należącym do nich sadem i ogrodem, blisko drogi wiodącej do wsi Bujny. Folwark Antoniewiczów znajdował się więc mniej więcej w okolicach dzisiejszego Placu Kościuszki i Alei 3-go Maja / Placu Niepodległości. Głównym punktem folwarku był niewielki dworek, nie zachowały się jednak jego opisy, zob.: APPT: Hipoteka Miasta Piotrkowa (dalej: HMP), sygn. 26, Kontrakt rezygnacji z praw do folwarku zwanego Krasiczyzna zawarty między Marianna z Kałowskich Głębocka a Antonim Kraśnickim, 1 IV 1784 r., nlb.

42 APPT: CKP, sygn. 32, s. 338; sygn. 7, s. 247. 
czając Piotrków na początku lat 70. XVIII wieku, mieli uregulowane wszystkie zobowiązania finansowe, o tyle Augustynowicz swych długów nie spłacił aż do śmierci ${ }^{43}$. W 1765 roku był zadłużony u kilku wierzycieli. Ponieważ jego spadkobiercy nie byli w stanie spłacić długów ojca, wierzyciele zajęli położoną przy Rynku kamienicę, z której czerpali zyski. Rodzinnej nieruchomości Augustynowiczowie nie odzyskali już nigdy ${ }^{44}$.

Poza kapitałem elementem nieodzownym w handlu winem było posiadanie odpowiedniego pomieszczenia magazynowego, gdzie towar można było składować. Funkcję tę w mieście średniowiecznym i nowożytnym pełniły piwnice mieszczańskich kamienic. Kupcy ormiańscy - bogaci i cieszący się dużym prestiżem społecznym - byli właścicielami okazałych nieruchomości położonych przy piotrkowskim Rynku ${ }^{45}$. To właśnie te kamienice posiadały najgłębsze i najbardziej rozległe piwnice. W kamienicy Augustynowiczów piwnica o gotyckich sklepieniach jest najstarszą zachowaną częścią budynku. Ciągnie się ona przez całą kamienicę od Rynku wzdłuż ul. Łaziennej Mokrej. Funkcję magazynu, w którym składowano beczki z winem pełniła jej południowa część. To właśnie w tej części od strony ul. Łaziennej zachowała się ,,szyja”, przez którą po specjalnych szynach spuszczano beczki. Przednia część piwnicy mogła być szynkiem lub wykorzystywano ją w produkcji piwowarskiej ${ }^{46}$.

Do naszych czasów zachowało się bardzo niewiele XVII- i XVIII-wiecznych opisów piotrkowskich kamienic mieszczańskich, w tym i piwnic. Szczęśliwie

43 APPT: HMP, sygn. 1038, k. 23-24.

${ }^{44}$ Ibidem, sygn. 59, Ustalenie praw dziedziczenia spadkobierców Stefana i Franciszki Augustynowiczów, 12 lipca 1832 r., nlb. Wierzyciele Stefana Augustynowicza zostali spłaceni przez Antoniego Maruszewskiego, który zgodnie z prawem do czasu skwitowania spadkobierców Augustynowicza użytkował przyrynkową kamienicę. Jego syn Tomasz sprzedał nieruchomość rodzinie Wojciechowskich, co spotkało się z protestem dzieci zmarłego Augustynowicza: Piotra i Teresy. O odzyskanie kamienicy ubiegali się aż do 1804 roku. Ponieważ oboje nie mieli potomstwa, prawa do nieruchomości przenieśli na potomków przyrodniej siostry Barbary Marianny. Ci zabiegali o odzyskanie kamienicy do 1834 roku, kiedy prawnuk Stefana Augustynowicza, Ernest Hildebrand, zrzekł się do niej praw.

${ }^{45} \mathrm{~W}$ przeciwieństwie do innych starych i znaczących w historii Polski ośrodków miejskich Piotrków nie doczekał się do tej pory badań nad kamienicami mieszczańskimi. Skromne analizy dotyczące zabudowy Rynku w latach 70. XX wieku podjął jedynie Kazimierz Głowacki. Należy żałować, że badacz nie zdecydował się ich kontynuować. Niewykonana przez niego kwerenda w aktach hipotecznych, choć żmudna i czasochłonna, z całą pewnością przyniosłaby wiele bardzo ciekawych wniosków, wzbogacając obecny stan wiedzy o zabudowie Piotrkowa $\mathrm{w}$ dobie staropolskiej. W ślad za badaniami źródłowymi powinny również pójść zaawansowane badania terenowe i archeologiczne. Te niestety, pomimo coraz większych możliwości technicznych, prowadzi się jedynie w niezwykle wąskim zakresie przy okazji remontów lub inwestycji budowlanych.

${ }^{46}$ Od strony ul. Łaziennej Mokrej zachowały się dawne otwory wentylacyjne niezbędne przy kontrolowaniu procesu fermentacji. Należy ubolewać, że po ostatnim remoncie części elewacji nieruchomości dwa z tych otworów zostały zamurowane. 
w aktach miejskiej hipoteki udało się odnaleźć ciekawy, pochodzący z XVIII wieku, opis kamienicy należącej do ormiańskiej rodziny Derjakubowiczów. W opisie szczególną uwagę zwracają trzy rozległe piwnice, w które wyposażona była ta nieruchomość. Pierwsza znajdowała się w południowej, druga zaś w północnej części budynku. Trzecia ulokowana została pod sienią i podcieniami. Od strony Rynku znajdowała się „,szyja” ${ }^{\text {47 }}$. Obszerne piwnice posiadała także położona na rogu Rynku i ówczesnej ul. Krótkiej kamienica Pieściochów, która była własnością teścia, a po jego śmierci należała do żony (do spółki z bratem) Antoniego Muratowicza. Przejął on zresztą po zmarłym teściu interes winiarski, prowadząc go z dużym powodzeniem, choć o jego działalności na tym polu zachowało się niewiele wzmianek. Od czerwca 1759 roku do czerwca roku następnego sprowadził łącznie 46 beczek wina ${ }^{48}$, co czyniło go jednym z największych handlarzy szlachetnym trunkiem w Piotrkowie.

Czas, w którym Muratowicz angażował się w handel winem, nie był jednak pomyślny dla piotrkowskich Ormian. Choć w XVII, a zwłaszcza w XVIII wieku, kupcy ormiańscy odgrywali niezwykle istotną rolę na miejscowym rynku handlu alkoholem, w połowie XVIII stulecia znacząco nasiliła się konkurencja „Węgrzynów”, czyli w głównej mierze prawosławnych kupców, przede wszystkim greckiego pochodzenia. Osiedliwszy się w podmiejskich jurydykach, trudnili się oni importem wina. Wkrótce okazało się, że zrzeszeni w Konfraterni Kupieckiej winiarze, w tym Ormianie, nie byli w stanie sprostać ich konkurencji. Na niewiele się zdały protesty i interwencje kierowane do piotrkowskiego starosty, a nawet do samego króla. W 1768 roku Grecy, dotychczas pozbawieni możliwości osiedlenia się w obrębie murów miejskich, mocą uchwały sejmowej uzyskali prawo kupowania nieruchomości na obszarze miasta właściwego oraz prawo do wstępowania

${ }^{47}$ APPT: HMP, sygn. 37, nlb. Ponieważ jest to jedyny znany opis kamienicy należącej do rodziny ormiańskiej, warto w tym miejscu przytoczyć inne jego dane. Kamienica była dwupiętrowa i jak wynika z przechowywanego w Bibliotece Jagiellońskiej rysunku piotrkowskiego Rynku, zwieńczona była barokowym szczytem, a jej fasadę zdobiły pilastry. Do sieni kamienicy wchodziło się z Rynku przez potężne drzwi z okuciami. Po prawej stronie od wejścia znajdowała się izdebka sięgająca do połowy długości sieni. Prowadziły do niej potrójne drzwi. W środku były ustawione szafki i ablatury. Za izdebką, na tyłach domu, zlokalizowana była kuchnia z oknami wychodzącymi na podwórze. Po lewej stronie sieni, bezpośrednio od strony podcienia, mieścił się sklep towarowy. Wejście dla klientów znajdowało się w podcieniu. W sklepie stał stół z regałem o szesnastu półkach. Poza drzwiami frontowymi od strony podcienia, sklep posiadał także bezpośrednie przejście do sieni. Na tyle domu była zlokalizowana duża izba z wysokim belkowanym stropem złożonym z dziewięciu belek. Od strony podwórza do sieni przylegał ganek prowadzący na podwórze kamienicy. W ganku były umieszczone schody na wyższe piętra. Na pierwszym piętrze znajdowała się izba z oknami na Rynek i połączona $\mathrm{z}$ nią garderoba. Na drugie piętro wchodziło się schodami z galerią i poręczami. Znajdowały się tam dwie izby z przylegającą do nich kuchnią. Jedyną zachowaną częścią dawnej kamienicy jest usytuowana po lewej stronie sklepiona sień.

${ }^{48}$ APPT: CKP, sygn. 7, s. 125. 
do miejskich korporacji zawodowych ${ }^{49}$. Niemogący sprostać greckiej konkurencji Ormianie zaczęli opuszczać Piotrków i przenosić się do innych ośrodków miejskich. Ich miejsce zajęli kupcy greccy oraz po części włoscy, czyli przedstawiciele tych nacji, które dominowały w handlu winem w Piotrkowie w XVI wieku.

\section{Bibliografia}

\section{Źródła archiwalne}

Archiwum Główne Akt Dawnych w Warszawie: Archiwum Skarbu Koronnego, dział I, sygn. 25; Sumariusze i księgi pomocnicze urzędu grodzkiego sieradzkiego oraz varia z akt ziemskich i grodzkich wielkopolskich, sygn. 38; Wypisy dekretów odnośnie czopowego z miast województwa sieradzkiego

Archiwum Narodowe w Krakowie: Akta Miasta Krakowa

Archiwum Państwowe w Piotrkowie Trybunalskim: Cech Kupców w Piotrkowie, sygn. 7; Akta Bractwa Kupieckiego Piotrkowskiego 1722-1759. Protokoły sesji, sygn. 32; Rejestr Bractwa Kupieckiego. Kwartalne wpływy i wydatki 1670-1731; Hipoteka Miasta Piotrkowa, sygn. 37

\section{Opracowania}

Dziubiński A., Na szlakach Orientu. Handel między Polska a Imperium Osmańskim w XVI-XVIII wieku, Wrocław 1998

Flatt O., Opis Piotrkowa Trybunalskiego pod względem historycznym i statystycznym, Warszawa 1850

Flatt O., Piotrków dziś i przed dwudziestu laty, w: J. Jaworski, Kalendarz astronomiczno-gospodarski na rok zwyczajny 1854. Opisów roślin rok siedemnasty, Warszawa 1854

Lewicki S., Drogi handlowe w Polsce w wiekach średnich i wieku XVI, Warszawa 1926

Majewski M. Ł., Kupcy ormiańscy w mieście staropolskim na przykładzie Piotrkowa Trybunalskiego, w: Ormianie - historia i kultura. Sesja naukowa Szreniawa, 24-25 czerwca 2017, red. A. A. Zięba, Szreniawa 2017

Majewski M., Parafia prawosławna p.w. Wszystkich Świętych z siedziba w Piotrkowie Trybunalskim w latach 1788-1939, KUL - Lublin 2018, praca doktorska

Majewski M. Ł., Piwowarstwo miejskie w Piotrkowie w XVI-XVIII wieku, niepublikowane opracowanie

Majewski M. Ł., Wẹgrzy, Szkoci i Ormianie. Studia nad składem etnicznym mieszkańców Piotrkowa przyjętych do prawa miejskiego w okresie staropolskim, Warszawa 2017

Marcinek R., Rex vinorum. Z dziejów węgrzyna w dawnej Polsce, Warszawa 2015

Pełczyński G., Polska - Ormianie - Wschód, w: Ormianie, red. B. Machul-Telus, Warszawa 2014

Rawita-Witanowski M., Monografia Piotrkowa Trybunalskiego, Piotrków Trybunalski 2017

49 M. Ł. Majewski, Parafia prawosławna p.w. Wszystkich Świętych z siedziba w Piotrkowie Trybunalskim w latach 1788-1939, KUL - Lublin 2018, praca doktorska. 
Weryha-Darowski A., Przystowia polskie odnoszace się do nazwisk szlacheckich i miejscowości, Poznań 1874

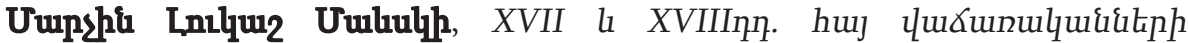

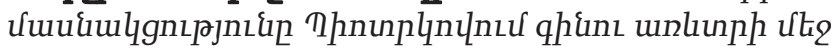

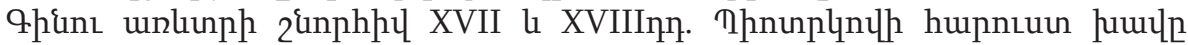

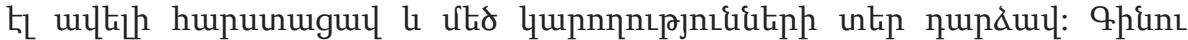

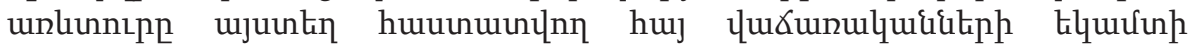

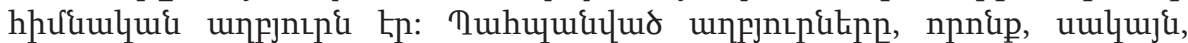

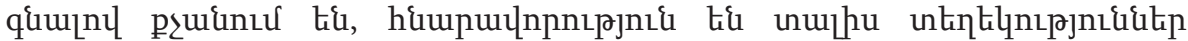

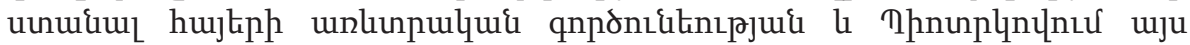

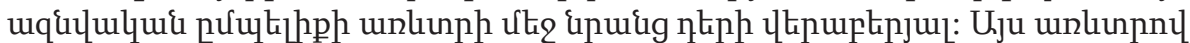

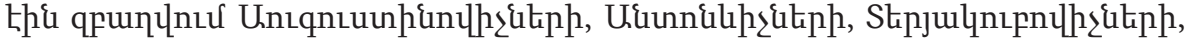

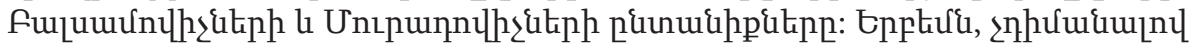

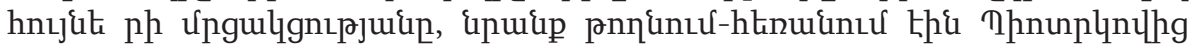

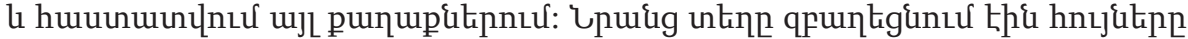

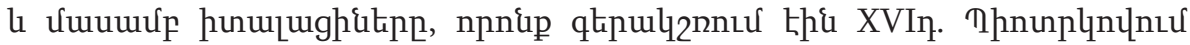
qhint unliunph utiq:

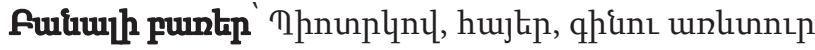

Marcin Lukasz Majewski, Armenian Tradesmen's Share in Wine Trade in Piotrków in the $17^{\text {th }}$ and $18^{\text {th }}$ Centuries

In the $17^{\text {th }}$ and $18^{\text {th }}$ the patriciate in Piotrków amassed fortune due to profits from wine trade activity. The profits also were going to Armenian pockets, as Armenian tradesmen were settling in town. The preserved sources, however scarce, help trace Armenian commercial activity and define its status on the local wine market. At that time the following Armenian families dealt in wine: the Augustynowicz, the Antoniewicz, the Derjakubowicz, the Balsamowicz, and the Muradowicz. As Greek commercial competitors grew stronger, Armenians gradually moved to other urban centres. Both Greek and Italian tradesmen soon came to replace them in Piotrków. They used to dominate that market in the $16^{\text {th }}$ century.

Keywords: Piotrków, Armenians, wine trade 